\title{
An ATM/Chk2-mediated DNA damage responsive signaling pathway suppresses Epstein-Barr virus transformation of primary human B cells
}

\author{
Pavel Nikitin', Chris Yan', Eleonora Forte', Alessio Bocedi', Jay Tourigny' ${ }^{1}$, Amee Patel ${ }^{2}$, Sandeep Dave², \\ Katherine Hu', Jing Guo', David Tainter ${ }^{1}$, Olena Rusyn', Micah Luftig ${ }^{1 *}$ \\ From $12^{\text {th }}$ International Conference on Malignancies in AIDS and Other Acquired Immunodeficiencies \\ (ICMAOI)
}

Bethesda, MD, USA. 26-27 April, 2010

Epstein-Barr virus (EBV) infection of primary B cells leads to the outgrowth of indefinitely proliferating lymphoblastoid cell lines (LCLs). However, the efficiency of immortalization is less than $10 \%$ of infected cells. We hypothesize that a robust innate tumor suppressor response prevents long-term outgrowth of the majority of infected cells. In this study we identify the DNA damage response (DDR) as a major component of this response. EBV infection of primary $B$ cells activated hallmarks of the DDR including phosphorylated ATM, Chk2, g-H2AX, and 53BP1 foci. DDR activation was not due to lytic viral DNA replication nor did its marks co-localize with latent viral episomes. Rather, EBV induced a period of hyper-proliferation early after infection responsible for DDR activation. Microarray data supported the transient activation and subsequent attenuation of proliferation and DDR-associated mRNAs during LCL outgrowth. Importantly, activation of this pathway suppressed transformation as small molecule antagonism of the DNA damage responsive kinases ATM and Chk2 increased EBV transformation efficiency. Thus, we propose a model whereby EBV infection initially drives aberrant cellular DNA replication activating an anti-proliferative DNA damage response. Long-term outgrowth depends on attenuation of this hyper-proliferative signal through full latency III gene expression.

\footnotetext{
* Correspondence: micah.luftig@duke.edu

'Department of Molecular Genetics and Microbiology, Center for Virology,

Duke University School of Medicine, Durham, NC, USA

Full list of author information is available at the end of the article
}

\section{Acknowledgements}

This article has been published as part of Infectious Agents and Cancer Volume 5 Supplement 1, 2010: Proceedings of the $12^{\text {th }}$ International Conference on Malignancies in AIDS and Other Acquired Immunodeficiencies (ICMAOI). The full contents of the supplement are available online at http://www.biomedcentral.com/1750-9378/5? issue=S1 .

\section{Author details}

'Department of Molecular Genetics and Microbiology, Center for Virology, Duke University School of Medicine, Durham, NC, USA. ²Duke Institute for Genome Sciences and Policy, Duke University, Durham, NC, USA.

Published: 11 October 2010

doi:10.1186/1750-9378-5-S1-A4

Cite this article as: Nikitin et al: An ATM/Chk2-mediated DNA damage responsive signaling pathway suppresses Epstein-Barr virus transformation of primary human B cells. Infectious Agents and Cancer 2010 5(Suppl 1):A4.
Submit your next manuscript to BioMed Central and take full advantage of:

- Convenient online submission

- Thorough peer review

- No space constraints or color figure charges

- Immediate publication on acceptance

- Inclusion in PubMed, CAS, Scopus and Google Scholar

- Research which is freely available for redistribution

Submit your manuscript at www.biomedcentral.com/submit
C Biomed Central 